\title{
Pengembangan E-Modul Fisika Dasar untuk Mahasiswa Calon Guru SMK Teknik Konstruksi dan Properti
}

\author{
M. Agphin Ramadhan, Santoso Sri Handoyo, M. Mahameru Alfarisi \\ Pendidikan Teknik Bangunan, Universitas Negeri Jakarta \\ *Email: agphin@unj.ac.id
}

Received: 14 Oktober 2020; Accepted: 16 Desember 2020; Published: 17 Desember 2020 DOI: http://dx.doi.org/10.29303/jpft.v6i2.2108

\begin{abstract}
Students of the Building Engineering Education (PTB) study program, as prospective teachers of the Construction and Property Engineering Vocational School (TKP), need to master physics subject matter extensively and deeply. Hopefully, when they become teachers, vocational students can be interested in physics subjects. This study aims to produce an e-module for introductory physics courses for prospective TKP SMK teachers. This study uses the Research and Development $(R \& D)$ method and uses the 4D development model, which consists of four main stages: Define, Design, Development, and Disseminate. Feasibility assessment by media experts obtained a percentage of the validity of the e-module by $90 \%$ and included in the very feasible category in terms of media. The feasibility assessment by material experts obtained an average percentage of e-module validity data that is $82 \%$, and it falls into the very feasible category in terms of material. The limited trial results showed that the mean score of participants during the pre-test was 64, and there was an increase to 89 after following the post-test. The results of the product user assessment obtained a value of 84.8 in the very feasible category. The results of validation tests and user responses concluded that the e-module for introductory physics courses is very suitable for teaching material for PTB students, prospective TKP vocational teachers.
\end{abstract}

Keywords: Teaching Materials; E-Module; Basic Physics

\section{PENDAHULUAN}

Program Keahlian Teknik Konstruksi dan Properti (TKP) merupakan salah satu program keahlian di SMK. Berdasarkan spektrum SMK 2018, program keahlian tersebut terdiri dari empat kompetensi keahlian, yaitu: 1) Konstruksi Gedung, Sanitasi, dan Perawatan, 2) Konstruksi Jalan, Irigasi, dan Jembatan, 3) Bisnis Konstruksi dan Properti, dan 4) Desain Pemodelan dan Informasi Bangunan. Dalam menyiapkan guru SMK program keahlian TKP, program studi Pendidikan Teknik Bangunan (PTB) UNJ selain memperbarui konten mata kuliah dengan perkembangan teknologi di industri konstruksi, juga mengacu pada perkembangan kurikulum di SMK.

Salah satu mata pelajaran di SMK yang menjadi momok bagi siswa adalah mata pelajaran Fisika. (Hartini, 2011) menyatakan bahwa semangat belajar siswa SMK pada mata pelajaran Fisika tergolong rendah. Hal ini diperkuat (Arini \& Juliadi, 2018) yang menyatakan kemampuan berpikir kritis siswa SMK pada mata pelajaran Fisika pada kategori rendah. Di SMK Program Keahlian TKP, mata pelajaran Fisika diberikan alokasi waktu 108 jam dengan rincian 3 jam pelajaran per minggu pada kelas $\mathrm{X}$ semester 1 dan 2. (U.S et al., 2015) menjelaskan bahwa faktor utama kurangnya minat siswa pada mata pelajaran Fisika adalah kurangnya kemampuan guru dan kekurangtepatan guru dalam memilih media pembelajaran (Syahputra et al., 2020).

Sebagai calon guru SMK TKP, mahasiswa program studi PTB perlu disiapkan dengan baik agar menguasai materi pelajaran secara luas dan mendalam (Apriani, 2017). Lebih lanjut (Wijaya, 2017) menyatakan bahwa mahasiswa PTB penting untuk memahami ilmu-ilmu dasar teknik. Hal ini untuk memperkuat pemahaman keilmuan teknik, salah satunya pada mata 
pelajaran Fisika. (Ridlo et al., 2018) menyatakan, guru kejuruan memiliki setidaknya empat peran penting dalam mengembangkan keterampilan kerja siswa, yaitu peran guru sebagai demonstran, sebagai mediator, sebagai evaluator dan sebagai individu yang kompeten. Dalam menyiapkan individu yang kompeten tersebut, calon guru sejak menjalani perkuliahan di LPTK (Lembaga Pendidikan dan Tenaga Kependidikan) perlu mendapatkan pembelajaran sesuai dengan perkembangan teknologi yang saat ini sedang berkembang.

Di LPTK, terdapat mata kuliah Fisika Dasar yang diberikan pada mahasiswa PTB di semester pertama. Di UNJ, mata kuliah tersebut fokus pada materi mekanika dan fisika bangunan. Media pembelajaran yang selama ini digunakan oleh dosen pengampu berbasis visual, yaitu menggunakan bahan tayang Microsoft Power Point. Pengembangan media pembelajaran mata kuliah Fisika Dasar yang selama ini dikembangkan, paling tidak dibagi menjadi tiga, yaitu: 1) pengembangan berbasis LMS (Herayanti et al., 2017), (Chanafi \& Mursal, 2016), (Hamka \& Effendi, 2019), (Widyawati et al., 2018), (Sari, 2020), (Devayanti, 2020); 2) pengembangan berbasis alat peraga, diantaranya: film (Asyari, 2017), media kartun (Setyono, 2014), animasi (Yusuf, 2015), dan lampu otomatis (Romadon \& Maryam, 2019); 3) pengembangan berbasis perangkat lunak, diantaranya: android (Hendri Adi et al., 2020), (Arrobbani, 2016) dan software DIALux (Wati, 2020).

Berdasarkan pengembanganpengembangan media yang telah ada dan menurut (Rivalina, 2017) pengembangan media perlu memperhatikan kemampuan pengguna dan sarana prasarana maka ditentukan media pembelajaran yang akan dikembangkan adalah e-modul. Menurut
(Laili, 2019) salah satu keunggulan e-modul adalah mampu menumbuhkan motivasi bagi peserta didik, mudah penggunaan (Puspitasari, 2019), dan dapat menampilkan atau memuat gambar, audio, video dan animasi serta dilengkapi tes formatif yang memungkinkan umpan balik otomatis dengan segera (Arsal et al., 2019). Oleh karena itu, tujuan penelitian ini adalah untuk mengembangkan e-modul mata kuliah Fisika Dasar untuk mahasiswa calon guru SMK program keahlian TKP.

\section{METODE PENELITIAN}

Desain penelitian dan pengembangan ini menggunakan model 4D (Define, Design, Development, Disseminate). Penelitian dan pengembangan bertujuan untuk menghasilkan produk bahan ajar berupa emodul mata kuliah Fisika Dasar. Tahapan penelitian dan pengembangannya terdiri dari: penetapan, perancangan, pengembangan, dan penyebaran.

Pada tahap penetapan, terdiri dari dua tahap, yaitu: analisis awal akhir dan analisis karakteristik peserta didik. Pada tahap perancangan dilakukan pembuatan produk emodul. Kemudian pada tahap pengembangan dilakukan validasi oleh ahli materi dan ahli media. Terakhir, pada tahap penyebaran, produk e-modul diberikan kepada peserta didik untuk diuji coba pada proses pembelajaran.

Metode pengumpulan data pada tahap penetapan (define) adalah angket, wawancara, dan dokumentasi. Kemudian, pada tahap pengembangan (development) data dikumpulkan melalui angket yang diberikan kepada validator. Hasil yang diperoleh digunakan sebagai bahan pertimbangan dalam memperbaiki media pembelajaran.

Aspek yang dinilai oleh validator ahli media, antara lain: tampilan desain, kemudahan, pemanfaatan, konsistensi dan 
format, dan kegrafikan. Adapun aspek yang dinilai oleh validator materi, yaitu: isi, bahasa, penyajian, tugas, dan rangkuman.. Dalam penelitian ini, angket yang diberikan kepada validator menggunakan skala likert 1 sampai 5. Tingkat validitas dihitung dengan

validitas $=\frac{\text { Perolehan Skor }}{\text { Skor Maksimum }} \times 100$

Hasil tingkat validitas tersebut kemudian dikategorikan berdasarkan tabel 1 .

Tabel 1. Interpretasi Skor Kelayakan

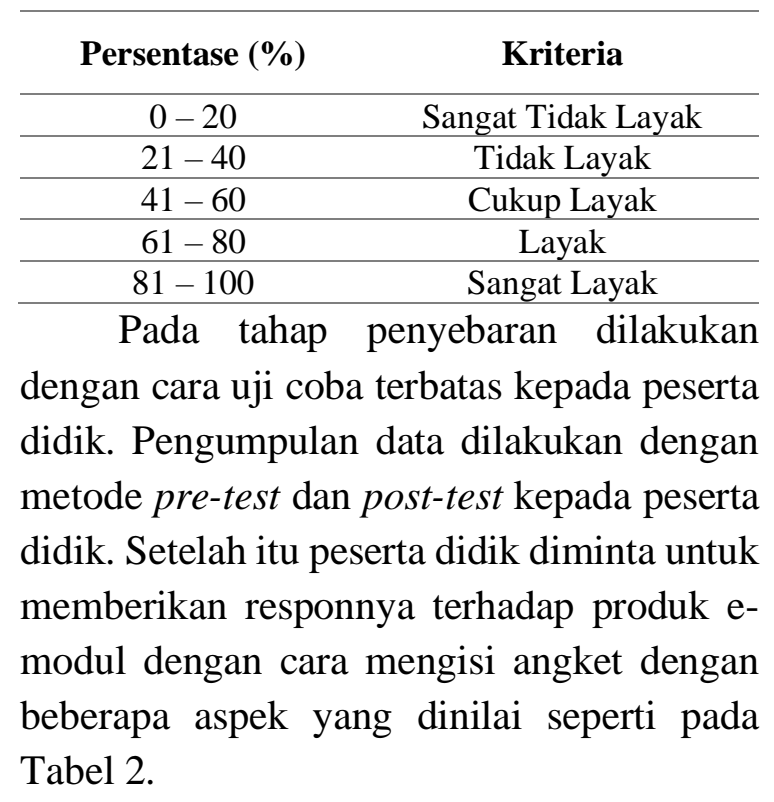

Tabel 2. Aspek yang Dinilai oleh Pengguna

\begin{tabular}{|c|c|c|}
\hline No & Aspek & Pertanyaan \\
\hline 1. & \multirow{3}{*}{$\begin{array}{l}\text { Desain } \\
\text { Tampilan }\end{array}$} & Desain sampul \\
\hline 2. & & Pemilihan jenis font \\
\hline 3. & & Pemilihan warna \\
\hline 4. & \multirow[t]{3}{*}{ Kemudahan } & Kemudahan pengunaan \\
\hline 5. & & Petunjuk penggunaan \\
\hline 6. & & Tombol navigasi \\
\hline 7. & \multirow[t]{4}{*}{$\begin{array}{l}\text { Materi } \\
\text { Evaluasi }\end{array}$} & $\begin{array}{l}\text { Memotivasi untuk belajar } \\
\text { mandiri }\end{array}$ \\
\hline 8. & & Pemilihan Bahasa \\
\hline 9. & & Kejelasan isi \\
\hline 10. & & Tes formatif \\
\hline
\end{tabular}

Teknik analisis data yang digunakan adalah deskriptif. Hasil validasi oleh ahli media dan materi, serta hasil penyebaran (disseminate) akan dideskripsikan atau digambarkan sesuai dengan data yang didapatkan, baik berupa grafik atau tabel.

\section{HASIL DAN PEMBAHASAN}

Pada tahap penetapan (define) dilakukan dua tahap. Pertama, Analisis Awal-Akhir. Pada tahap ini dilakukan wawancara dengan dosen pengampu mata kuliah Fisika Dasar dan menyebarkan angket kepada mahasiswa angkatan 2018 dan 2019. Berdasarkan hasil wawancara diketahui bahwa selama ini mahasiswa hanya berfokus pada materi yang disampaikan melalui bahan tayang powerpoint dan tidak mencari sumber lain sebagai bahan ajar, sehingga dibutuhkan pengembangan produk bahan ajar yang dapat dijadikan pedoman dalam pembelajaran. Kemudian berdasarkan angket yang disebarkan kepada 90 mahasiswa, menyatakan bahwa $100 \%$ responden menjawab perlu dilakukan pengembangan bahan ajar pada mata kuliah Fisika Dasar. Sejumlah 57,8\% responden lebih memilih e-modul untuk diterapkan pada mata kuliah Fisika Dasar. Kedua, tahap analisis karakteristik peserta didik. Pada tahap ini dilakukan analisis hasil belajar mata kuliah Fisika Dasar. Berdasarkan data nilai UTS didapat nilai rata-rata mahasiswa sebesar 65,6. Hal ini menunjukkan kemampuan mahasiswa belum maksimal.

Pada tahap perancangan, produk emodul disusun dengan mengacu pada RPS (Rencana Pembelajaran Semester) mata kuliah Fisika Dasar tahun 2019. Produk emodul terdiri dari tiga bagian utama, bagian awal, materi, dan penutup. Pada bagian awal e-modul terdapat halaman sampul, daftar isi, petunjuk penggunaan e-modul, serta pendahuluan. Pada bagian materi berisi pembahasan utama materi pembelajaran yang disusun berdasarkan RPS. Bagian penutup e-modul ini terdiri dari Rangkuman, Tes Formatif yang bertujuan untuk mengetahui pencapaian kompetensi mahasiswa, Glosarium, dan Daftar Pustaka. Tampilan halaman sampul, daftar isi, contoh materi, dan contoh soal pada e-modul 
disajikan pada Gambar 1.

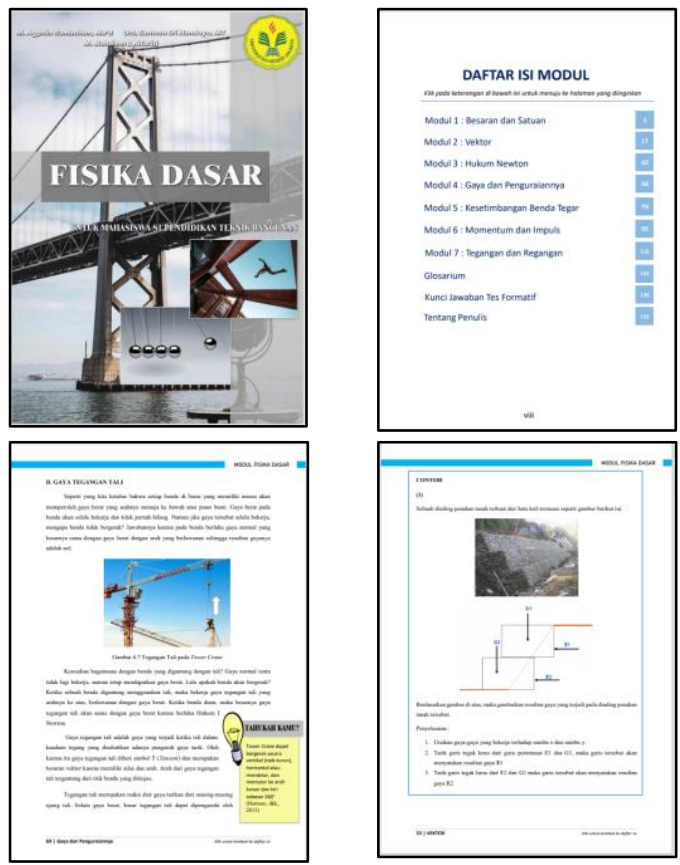

Gambar 1. Tampilan E-Modul Fisika Dasar

Pada tahap pengembangan, dilakukan validasi oleh ahli media dan ahli materi. Berdasarkan masukan dari ahli media, terdapat beberapa perbaikan, antara lain: perubahan warna font dan background, perbaikan gambar yang kurang jelas, dan konsistensi penggunaan tabel. Adapun penilaian aspek disajikan pada tabel 3 .

Tabel 3. Hasil Validasi dari Ahli Media

\begin{tabular}{lllll}
\hline \multirow{2}{*}{ Aspek } & \multicolumn{2}{c}{ Skor } & \multirow{2}{*}{ Persentase } & Kategori \\
\cline { 2 - 5 } & Ahli & Maks, & & \\
\hline $\begin{array}{l}\text { Tampilan } \\
\text { desain }\end{array}$ & 14 & 15 & $93 \%$ & $\begin{array}{l}\text { Sangat } \\
\text { Layak }\end{array}$ \\
\hline Kemudahan & 28 & 30 & $93 \%$ & $\begin{array}{l}\text { Sangat } \\
\text { Layak }\end{array}$ \\
\hline Pemanfaatan & 22 & 25 & $88 \%$ & $\begin{array}{l}\text { Sangat } \\
\text { Layak }\end{array}$ \\
\hline $\begin{array}{l}\text { Konsistensi } \\
\text { dan format }\end{array}$ & 23 & 25 & $92 \%$ & $\begin{array}{l}\text { Sangat } \\
\text { Layak }\end{array}$ \\
\hline Kegrafikan & 16 & 20 & $80 \%$ & Layak \\
\hline Total & 103 & 115 & $90 \%$ & $\begin{array}{l}\text { Sangat } \\
\text { Layak }\end{array}$ \\
\hline
\end{tabular}

Berdasarkan tabel 3 dapat disimpulkan bahwa e-modul Fisika Dasar telah memenuhi ke-5 aspek media dan masuk kategori sangat layak. Selanjutnya pada proses validasi dengan ahli materi, teradapat beberapa masukan, antara lain: perubahan beberapa kata, tambahan glosarium, sumber setiap gambar, perbaikan judul sub bab, dan peta konsep berupa diagram setiap modul. Adapun penilaian akhir masing-masing modul dari 2 validator disajikan pada tabel 4.

Tabel 4. Hasil Validasi dari Ahli Materi

\begin{tabular}{lcccc}
\hline \multirow{1}{*}{ Modul } & \multicolumn{2}{c}{$\begin{array}{c}\text { Penilaian } \\
(\boldsymbol{\%})\end{array}$} & $\begin{array}{c}\text { Rata- } \\
\text { rata }\end{array}$ & Kategori \\
\cline { 2 - 3 } & V1 & V2 & & \\
\hline $\begin{array}{l}\text { Besaran dan } \\
\text { Satuan }\end{array}$ & 81 & 82 & 81 & $\begin{array}{l}\text { Sangat } \\
\text { Layak }\end{array}$ \\
\hline $\begin{array}{l}\text { Vektor } \\
\text { Hukum }\end{array}$ & 81 & 81 & 81 & $\begin{array}{l}\text { Sangat } \\
\text { Layak }\end{array}$ \\
\hline $\begin{array}{l}\text { Newton } \\
\text { Gaya }\end{array}$ & 81 & 84 & 82 & $\begin{array}{l}\text { Sangat } \\
\text { Layak }\end{array}$ \\
$\begin{array}{l}\text { Penguraiannya } \\
\text { Kesetimbangan }\end{array}$ & 81 & 86 & 83 & $\begin{array}{l}\text { Sangat } \\
\text { Layak }\end{array}$ \\
$\begin{array}{l}\text { Benda } \\
\text { Tegar }\end{array}$ & 81 & 86 & 83 & $\begin{array}{l}\text { Sangat } \\
\text { Layak }\end{array}$ \\
\hline $\begin{array}{l}\text { Impuls, } \\
\text { Momentum, } \\
\text { dan } \\
\text { Momen Inersia }\end{array}$ & 81 & 86 & 83 & $\begin{array}{l}\text { Sangat } \\
\text { Layak }\end{array}$ \\
\hline $\begin{array}{l}\text { Tegangan dan } \\
\text { Regangan }\end{array}$ & 81 & 83 & 82 & $\begin{array}{l}\text { Sangat } \\
\text { Layak }\end{array}$ \\
\hline
\end{tabular}

Berdasarkan tabel 4, hasil dari validasi oleh ahli materi dapat disimpulkan bahwa emodul mata kuliah fisika dasar memiliki total rata-rata persentase sebesar $82 \%$ yang menunjukkan bahwa e-modul yang dikembangkan masuk ke dalam kategori sangat layak.

Tahap penyebaran dilakukan setelah e-modul diperbaiki berdasarkan masukan dari validator. Penyebaran dilakukan dengan cara terbatas kepada mahasiswa. Metode yang digunakan berupa pre-test dan posttest. Tes ini digunakan untuk mengukur keefektifan produk sebelum dan setelah digunakan oleh pengguna. Hasil pre-test dan post-test disajikan pada gambar 2 . 
Hasil Pre-test \& Post-test

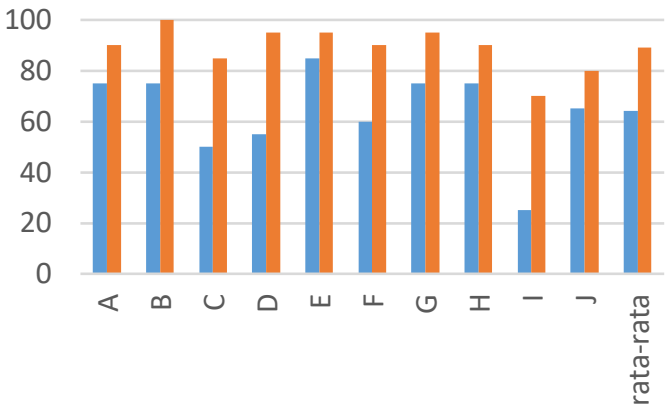

Pre-test $\quad$ Post-test

Gambar 2. Hasil Pre-test dan Post-test

Nilai pre-test merupakan kemampuan awal mahasiswa sebelum menggunakan e-modul. Adapun nilai post-test merupakan kemampuan mahasiswa setelah menggunakan e-modul. Berdasarkan grafik pada gambar 2 dapat disimpulkan bahwa terjadi peningkatan kemampuan mahasiswa dari 64 (rata-rata saat pre-test) ke 89 (ratarata saat post-test). Hasil respon pengguna terhadap e-modul dapat dilihat pada tabel 5.

Tabel 5. Penilaian Pengguna terhadap Produk

\begin{tabular}{|c|c|c|c|}
\hline Aspek & Pertanyaan & Persentase & Kategori \\
\hline \multirow{4}{*}{$\begin{array}{l}\text { Desain } \\
\text { Tampilan }\end{array}$} & Desain & 82 & Sangat \\
\hline & sampul & & Layak \\
\hline & Pemilihan & 92 & Sangat \\
\hline & $\begin{array}{l}\text { Pemilihan } \\
\text { warna }\end{array}$ & 78 & Layak \\
\hline \multirow[t]{3}{*}{ Kemudahan } & $\begin{array}{l}\text { Kemudahan } \\
\text { pengunaan }\end{array}$ & 84 & $\begin{array}{l}\text { Sangat } \\
\text { Layak }\end{array}$ \\
\hline & $\begin{array}{l}\text { Petunjuk } \\
\text { penggunaan }\end{array}$ & 86 & $\begin{array}{l}\text { Sangat } \\
\text { Layak }\end{array}$ \\
\hline & $\begin{array}{l}\text { Tombol } \\
\text { navigasi }\end{array}$ & 88 & $\begin{array}{l}\text { Sangat } \\
\text { Layak }\end{array}$ \\
\hline \multirow[t]{4}{*}{$\begin{array}{l}\text { Materi \& } \\
\text { Evaluasi }\end{array}$} & $\begin{array}{l}\text { Memotivasi } \\
\text { untuk } \\
\text { belajar } \\
\text { mandiri }\end{array}$ & 80 & $\begin{array}{l}\text { Sangat } \\
\text { Layak }\end{array}$ \\
\hline & $\begin{array}{l}\text { Pemilihan } \\
\text { Bahasa }\end{array}$ & 86 & $\begin{array}{l}\text { Sangat } \\
\text { Layak }\end{array}$ \\
\hline & $\begin{array}{l}\text { Kejelasan } \\
\text { isi }\end{array}$ & 86 & $\begin{array}{l}\text { Sangat } \\
\text { Layak }\end{array}$ \\
\hline & Tes formatif & 86 & $\begin{array}{l}\text { Sangat } \\
\text { Layak }\end{array}$ \\
\hline Rata-rata & & 84,8 & $\begin{array}{l}\text { Sangat } \\
\text { Layak }\end{array}$ \\
\hline
\end{tabular}

Berdasarkan tabel 5 dapat dijelaskan bahwa pada semua aspek, baik desain tampilan, kemudahan, materi dan evaluasi berada pada kategori sangat layak. Hasil ini menunjukkan bahwa e-modul Fisika Dasar dapat diterima dengan baik oleh para pengguna. Pada aspek desain tampilan, emodul telah dirancang dengan jenis font dan pemilihan warna yang sesuai dengan kebutuhan visual membaca. Pada aspek kemudahan pengguna, e-modul dirancang secara terpisah sesuai materi sehingga ukuran file sekitar 5-7 MB. Selain itu, di dalam modul disertai QR Code dan link yang menuju website atau video tertentu yang berisi tentang penjelasan tambahan materi. Pada aspek materi, e-modul cukup komprehensif membahas materi-materi fisika yang berkaitan dengan Teknik Sipil. Sedangkan pada bagian evaluasi, pengguna dapat mengoreksi jawabannya langsung setelah selesai mengerjakannya.

Berdasarkan penjabaran sebelumnya, temuan utama dalam penelitian ini adalah produk pembelajaran berupa e-modul mata kuliah Fisika Dasar yang digunakan di prodi PTB. Pengguna e-modul ini adalah mahasiswa prodi PTB yang merupakan calon guru SMK program keahlian TKP. Keunggulan produk e-modul ini, antara lain: pertama, pengembangan materi fisika lebih dikaitkan dengan contoh-contoh permasalahan di bidang Teknik Sipil. Hal ini dikarenakan pengguna e-modul adalah mahasiswa prodi PTB, yang keilmuannya sangat relevan dengan bidang Teknik Sipil. Kedua, e-modul fisika yang dikembangkan sangat komprehensif pada materi-materi yang berkaitan dengan mekanika. Hal ini untuk mendukung pemahaman mahasiswa pada konsep mekanika teknik, yang merupakan ilmu dasar dalam perhitungan struktur bangunan. Ketiga, berdasarkan hasil validasi didapat bahwa e-modul sangat layak digunakan sebagai bahan ajar bagi 
mahasiswa PTB, calon guru SMK program keahlian TKP. Hasil penyebaran yang telah dilakukan kepada pengguna juga menunjukkan hal demikian, bahwa respon terhadap e-modul pada kategori sangat baik.

Berdasarkan penelusuran hasil-hasil penelitian pengembangan media pembelajaran mata kuliah Fisika Dasar selama 5 tahun terakhir didapat bahwa belum ada produk pembelajaran berupa emodul mata kuliah Fisika Dasar untuk mahasiswa PTB dan Teknik Sipil. Pengembangan media pembelajaran mata kuliah Fisika yang selama ini dilakukan sangat dominan pada media pembelajaran yang berbasis LMS, seperti: moodle (Herayanti et al., 2017) Edmodo (Hamka \& Effendi, 2019), e-learning (Widyawati et al., 2018), dan website (Chanafi \& Mursal, 2016). Adapun pengembangan e-modul pada mata kuliah Fisika dilakukan oleh (Matsun \& Saputri, 2020) yang mengembangkan e-modul mata kuliah Fisika berbantuan Whatsapp. E-Modul yang dikembangkan fokus pada materi Fisika Inti. (Pathoni et al., 2017) juga mengembangkan e-modul mata kuliah Fisika Atom dan Inti. (Ningsi \& Nasih, 2020) mengembangkan emodul mata kuliah Fisika hanya di materi pembiasan lensa cembung. (Ramdani, 2020) mengembangkan e-modul yang hanya fokus di materi deret tak hingga dan deret pangkah pada mata kuliah Fisika Matematika. Hasil penelitian-penelitian tersebut relevan dengan hasil penelitian ini. Sebagian besar emodul berada pada kategori layak pada aspek media dan materi. Hal ini wajar karena produk-produk pembelajaran tersebut telah melewati proses validasi dan perbaikan berdasarkan masukan dari berbagai pihak.

\section{PENUTUP}

Penelitian dan pengembangan yang dilakukan menghasilkan produk merupa emodul mata kuliah Fisika Dasar untuk mahasiswa prodi PTB UNJ, sebagai calon guru SMK Program Keahlian TKP. E-modul yang dikembangkan terdiri dari tiga bagian utama, bagian awal, materi, dan penutup. Pada bagian awal e-modul terdapat halaman sampul, daftar isi, petunjuk penggunaan emodul, serta pendahuluan. Pada bagian materi berisi pembahasan utama materi pembelajaran yang disusun berdasarkan RPS. Bagian penutup e-modul ini terdiri dari Rangkuman, Tes Formatif yang bertujuan untuk mengetahui pencapaian kompetensi mahasiswa, Glosarium, dan Daftar Pustaka. Produk akhir berupa e-modul ini telah melalui tahap validasi media dan materi. Hasil validasi media didapat skor sebesar 90\% dengan kategori sangat layak. Adapun hasil validasi materi mendapat skor $82 \%$ dengan kategori sangat layak. Selain itu, pada tahap penyebaran dilakukan uji coba penggunaan modul. Hasil pre-test dan post test menunjukkan peningkatan nilai dari 64 ke 89 . Respon pengguna terhadap e-modul ini berada pada skor $84,8 \%$ dengan kategori sangat layak.

Dalam mengembangkan produk pembelajaran, dalam hal ini e-modul perlu diperhatikan, hal-hal berikut ini: 1) peneliti perlu menentukan model pengembangan yang akan digunakan kemudian konsisten untuk melalui prosesnya sehingga hasil akhir yang didapat maksimal, 2) kebutuhan materi tidak hanya disesuaikan dengan RPS namun perlu menyesuaikan dengan contoh-contoh terapan di kehidupan sehari-hari, 3) peneliti juga sangat perlu memperhatikan karakteristik peserta didik sehingga produk yang akan dikembangkan sesuai dengan kebutuhan. Pengembangan e-modul Fisika Dasar ini terbatas pada tahap penyebaran skala kecil sehingga perlu dilanjutkan pada tahap penyebaran skala besar dengan cara digunakan pada awal perkuliahan di semester pertama bagi mahasiswa baru. 


\section{REFERENSI}

Apriani, R. (2017). Studi tentang Kesiapan Mahasiswa Prodi PTB DPTS FPTK UPI terhadap Kompetensi Profesional dan Sosial sebagai Calon Guru SMK Bidang Keahlian Teknik Bangunan. 2017.

Arini, W., \& Juliadi, F. (2018). Analisis Kemampuan Berfikir Kritis Pada Mata Pelajaran Fisika Untuk Pokok Bahasan Vektor Siswa Kelas X SMA NEGERI 4. Fisika, 10(1), 1-11. http://journal.uad.ac.id/index.php/BFI/ article/download/9485/4577

Arrobbani, A. (2016). Pengaruh Pengembangan Media Pembelajaran Berbasis Android Pada Mata Kuliah Fisika Teknik Untuk Mahasiswa Teknik Mesin Universitas Negeri Surabaya. Jurnal Pendidikan Teknik Mesin UNESA, 5(02), 250399.

Arsal, M., Danial, M., \& Hala, Y. (2019). Pengembangan Media Pembelajaran EModul Materi Sistem Peredaran Darah Pada Kelas XI MIPA SMAN 6 BARRU. Prosiding Seminar Nasional Biologi VI, 434-442.

Asyari, R. A. (2017). Penerapan Film Sebagai Media Pembelajaran pada Mata Kuliah Fisika Dasar. Jurnal EKOMTEK, 1(1), 76-88. http://library1.nida.ac.th/termpaper6/sd /2554/19755.pdf

Chanafi, B., \& Mursal, M. (2016). Pembelajaran Fisika Dengan Memanfaatkan Media Berbasis Teknologi Informasi Dan Komunikasi Untuk Meningkatkan Hasil Belajar Mahasiswa Pada Materi Biooptik. Jurnal Pendidikan Sains Indonesia, 4(2), 118-123.

Devayanti, H. (2020). Pengembangan Media Pembelajaran Berbasis Web Pada Mata Kuliah Fisika Modern. http://repository.untad.ac.id/3668/

Hamka, D., \& Effendi, N. (2019). Pengembangan Media Pembelajaran Blended Learning Berbasis Edmodo
Pada Mata Kuliah Fisika Dasar di Program Studi Pendidikan IPA. Journal of Natural Science and Integration, 2(1), https://doi.org/10.24014/jnsi.v2i1.7111

Hartini, P. (2011). Pengembangan Model Pembelajaran Fisika Smk Melalui Kegiatan Bengkel Otomotif Untuk. Jurnal PP, 1(No.2), 190-199.

Hendri Adi, N., Fernandes, A. L., \& Hermansyah, H. (2020). Pengembangan Media Pembelajaran Berbasis Android Pada Mata Kuliah Fisika Dasar. Cetta: Jurnal Ilmu Pendidikan, 3(1), 103-114. https://doi.org/10.37329/cetta.v3i1.414

Herayanti, L., Fuaddunnazmi, M., \& Habibi, H. (2017). Pengembangan Media Pembelajaran Berbasis Moodle pada Mata Kuliah Fisika Dasar. Jurnal Pendidikan Fisika Dan Teknologi, 1(3), 205.

https://doi.org/10.29303/jpft.v1i3.260

Laili, I. (2019). Efektivitas Pengembangan E-Modul Project Based Learning Pada Mata Pelajaran Instalasi. Jurnal Imiah Pendidikan Dan Pembelajaran, 3, 306315. https://ejournal.undiksha.ac.id/index.p hp/JIPP/article/download/21840/13513

Matsun, \& Saputri, D. F. (2020). Pengembangan E-Modul Fisika Berbantuan WhatsApp sebagai Alternatif Pembelajaran di Masa Pandemi Covid 19. ORBITA, 6(November), 213-220.

Ningsi, A. P., \& Nasih, N. R. (2020). Mendeskripsikan Keterampilan Proses Sains Mahasiswa Pendidikan Fisika Universitas Jambi pada Materi Pembiasan pada Lensa Cembung dengan Menggunakan E-Modul. 5(1), 35-43.

Pathoni, H., Jufrida, Saputri, I., \& Sari, W. (2017). Persepsi Mahasiswa terhadap E-Modul Pembelajaran Mata Kuliah Fisika Atom dan Inti. Jurnal Eksakta Pendidikan (JEP_, 1(1), 55-62. 
Puspitasari, A. D. (2019). Penerapan Media Pembelajaran Fisika Menggunakan Modul Cetak dan Modul Elektronik pada Siswa SMA. Jurnal Pendidikan Fisika, 7(1), 17-25.

Ramdani. (2020). Pengembangan E-Modul Berbasis Edmodo Pada Materi Deret Tak Hingga \& Deret Pangkat Mata Kuliah Fisika Matematika I. https://repository.unja.ac.id/id/eprint/1 4424

Ridlo, A., Jumintono, J., \& Achsan, B. N. (2018). the Teacher'S Role in Increasing Employability Skills of the Drawing Building Engineering Vocational High School Students. Journal of Vocational Education Studies, $\quad 1(1), \quad 13$. https://doi.org/10.12928/joves.v1i1.59 1

Rivalina, R. (2017). Strategi Pemanfaatan ELearning dalam Mengatasi Keterbatasan Jumlah Dosen. Jurnal Kwangsan, $\quad 5(2), \quad 17$ https://doi.org/10.31800/jurnalkwangs an.v5i2.46

Romadon, \& Maryam, E. (2019). Pengaruh Penggunaan Media Pembelajaran Lampu Otomatis Terhadap Hasil dan Motivasi Belajar Mahasiswa pada Mata Kuliah Fisika Listrik. SILAMPARI JPIF, 1(2), 1-13.

Sari, K. (2020). Efektifitas Pelaksanaan Pembelajaran Fisika Dengan Menggunakan Media E-Learning Pada Mata Kuliah Gelombang Dan Optik. https://etd.unsyiah.ac.id/index.php?p=s how_detail\&id=78153

Setyono, E. Y. (2014). Pengaruh Penggunaan Media Pembelajaran Kartun Fisika Terhadap Motivasi Belajar Mahasiswa pada Mata Kuliah Fisika Terapan. SOSHUM Jurnal Sosial Dan Humaniora, 4(3), 169-178.

Syahputra, A., Suparno, S., Giatman, M., \& Maulida, R. (2020). Perancangan Media Pembelajaran Interaktif Berbasis Model Pembelajaran Problem Based Learning Mata Kuliah Fisika
Dasar. Jurnal Media Informatika Budidarma, 4(1), 245. https://doi.org/10.30865/mib.v4i1.197 4

U.S, S., Leonard, Suhendri, H., \& Rismurdiyati. (2015). Pengaruh Media Pembelajaran Dan Minat Belajar. Pengaruh Media Pembelajaran Dan Minat Belajar Terhadap Hasil Belajar Fisika Supardi, 2(1), 71-81.

Wati, E. K. (2020). Penggunaan Software Optimasi Pencahayaan Sebagai Media Pembelajaran Mata Kuliah Fisika Bangunan. SAP (Susunan Artikel Pendidikan), 4(3). https://doi.org/10.30998/sap.v4i3.6281

Widyawati, W., Saehana, S., \& Wahyono, U. (2018). Pengembangan Media Pembelajaran Berbasis E-Learning Pada Mata Kuliah Fisika Modern. JPFT (Jurnal Pendidikan Fisika Tadulako Online), 6(1), 32. https://doi.org/10.22487/j25805924.20 18.v6.i1.10016

Wijaya, K. (2017). Evaluation of The Learning Program in The Building Construction Materials Course in Vocational Education. In Regionalization and Harmonization in TVET. Taylor \& Francis. https://doi.org/10.1201/978131516656 8

Yusuf, A. M. (2015). Pengembangan Media Pembelajaran Berbasis Adobe Flash untuk Mata Kuliah Fisika Modern. Jurnal Sains Dan Pendidikan Fisika, 11(1), 57-71. 